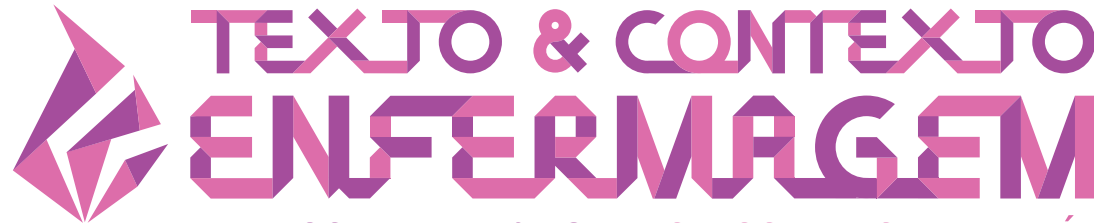

TEXT \& CONTEXT NURSING TEXTO \& CONTEXTO ENFERMERÍA

\section{FAMILY APPRAISAL OF THE DOWN SYNDROME DIAGNOSIS}

\section{Débora Lara Couto Schettini' ${ }^{1}$ Marcia Leigh Van Riper ${ }^{2}$ Elysângela Dittz Duarte ${ }^{3}$ (c)}

\footnotetext{
${ }^{1}$ Universidade Federal de Minas Gerais, Hospital das Clínicas. Belo Horizonte, Minas Gerais, Brasil. 2University of North Carolina, Chapel Hill. Carolina do Norte, Estados Unidos. ${ }^{3}$ Universidade Federal de Minas Gerais, Escola de Enfermagem. Belo Horizonte, Minas Gerais, Brasil.
}

\begin{abstract}
Objective: to analyze the family appraisal about the Down syndrome diagnosis.

Method: this is a qualitative, exploratory study, guided by the Resiliency Model of Family Stress, Adjustment, and Adaptation. Semi-structured interviews were conducted with 20 Brazilian parents of children with Down syndrome (19 mothers and 1 father). The data were collected between February and June 2016 and were analyzed using a directed content analysis approach and MAXQDA @ , version 12.2.0 software was used to help manage the data.

Results: the moment of suspected or confirmed diagnosis of Down syndrome occurred predominantly in the postnatal period. Parents viewed the experience of being informed of their child's diagnosis as a negative experience and were mostly dissatisfied with how professionals informed them. Parents reported that, over time, their view of having a child with Down syndrome became more positive.

Conclusion: the family's perception of how they were informed of their child's diagnosis plays a critical role in the family adaptation process and may ultimately contribute to how well they adapt. Findings from this study will help in the identification of key competencies needed by health professionals who engage in informing families about their child's diagnosis of Down syndrome.
\end{abstract}

DESCRIPTORS: Down Syndrome. Diagnosis. Family. Child. Psychological Adaptation. 


\section{APRECIAÇÃO FAMILIAR ACERCA DO DIAGNÓSTICO DE SÍNDROME DE DOWN}

\section{RESUMO}

Objetivo: analisar a apreciação familiar acerca do diagnóstico de síndrome de Down.

Método: trata-se de um estudo de abordagem qualitativa, do tipo exploratório, guiado pelo referencial teórico do modelo de resiliência, estresse, ajustamento e adaptação familiar. Entrevistas semiestruturadas foram realizadas com 20 pais brasileiros (19 mães e 1 pai), residentes em Belo Horizonte ou cidades próximas. Os dados foram coletados no período de fevereiro a junho de 2016 e analisados de acordo com a análise de conteúdo direta, utilizando-se o software MAXQDA@, versão 12.2.0.

Resultados: omomento da suspeita ou confirmação do diagnóstico da síndrome de Downfoi predominantemente no período pós-natal. Os pais referiram à experiência de ser informado sobre o diagnóstico da criança como negativa, e ficaram insatisfeitos, em sua maior parte com a forma como eles foram informados pelos profissionais. Os pais relataram que ao longo do tempo sua visão de ter uma criança com síndrome de Down se tornou mais positiva.

Conclusão: a percepção da família sobre como eles foram informados do diagnóstico da criança é determinante no processo de adaptação familiar e pode contribuir para a sua boa adaptação. Os achados deste estudo ajudarão na identificação de competências necessárias para o profssional de saúde que está envolvido em informar as famílias sobre o diagnóstico de sua criança com síndrome de Down.

DESCRITORES: Síndrome de Down. Diagnóstico. Família. Criança. Adaptação Psicológica.

\section{EVALUACIÓN FAMILIAR DEL DIAGNÓSTICO DEL SÍNDROME DE DOWN}

\section{RESUMEN}

Objetivo: analizar la evaluación familiar sobre el diagnóstico del síndrome de Down.

Método: este estudio cualitativo, exploratorio fue dirigido por el Modelo de Resiliencia al Estrés, Ajuste y Adaptación. Se realizaron entrevistas semi-estructuradas con 20 padres brasileños de niños con el síndrome de Down (19 madres y 1 padre). Los datos fueron recolectados entre febrero y junio del 2016 y fueron analizados mediante la aproximación del análisis de contenido dirigido y se utilizó el software MAXQDA @, versión 12.2.0 para ayudar a gestionar los datos.

Resultados: el momento del diagnóstico sospechado o confirmado del síndrome de Down ocurrió principalmente en el período postnatal. Los padres consideraron la experiencia de ser informado sobre el diagnóstico de sus hijos como negativa, y la mayoría estaba insatisfecha con como los profesionales se les informaron. Los padres relataron que, con el tiempo, su visión de tener un hijo con el síndrome de Down se hizo más positiva.

Conclusión: la percepción de la familia de como se les informó el diagnóstico de su hijo tiene papel crítico en el proceso de adaptación familiar y puede en última instancia contribuir a como de bien se adaptan. Los hallazgos de este estudio ayudaran en la identificación de competencias clave necesarias a profesionales de salud involucrados en informar a familias sobre el diagnóstico de sus hijos con el síndrome de Down.

DESCRIPTORES: Síndrome de Down. Diagnóstico. Familia. Niño. Adaptación Psicológica. 


\section{INTRODUCTION}

Down Syndrome (DS), the most common chromosomal cause of intellectual disability, is associated with a characteristic phenotype and a wide variety of co-occurring conditions such as congenital heart disease, hypothyroidism, and celiac disease. ${ }^{1-3}$ The number and severity of cooccurring conditions can vary greatly from one child with DS to the next, so no two children with DS are exactly alike.

The diagnosis of DS is an important and often unexpected event that can have profound implications not only for the child but also for other family members. While some families may struggle with the ongoing demands associated with DS, others adapt well and some thrive. ${ }^{4-5}$ The care needs of children diagnosed with DS go far beyond the demands found in families whose children have typical development. These extra care demands can negatively affect individual and family adaptation because they require family members to invest a great deal of time, patience, and energy into the care of the child with DS. ${ }^{5-6}$

Given the variability in how families respond following their child's diagnosis of DS, the families' experiences in various periods of the child's life need to be considered. It is also important to understand how critical events influence the ability of families to adapt to their situation. In this paper, we highlight the period when families first became aware of their child's diagnosis of DS. We chose this period because most families of children with DS consider it to be a critical event, with implications for their acceptance, adaptation, and willingness to follow recommendations for care. ${ }^{7}$

Investigations in the Brazilian and international context have indicated that at the time of diagnosis, families usually experience negative feelings, such as tension, anxiety, stress, denial, punishment, ${ }^{8}$ disorientation, loss of the idealized child during gestation, anxiety, ${ }^{9-10}$ shock, ${ }^{8,10,11}$ fear, sadness, anger, and frustration, ${ }^{8,12}$ concern with society's response in the future.15 A few families mentioned positive feelings. ${ }^{9}$

As far as research with families of children with DS from Brazil, there are relatively few studies. ${ }^{8,13-14}$ Most of the Brazilian studies explore aspects related to developmental issues, health care interventions, and other diseases associated with DS. ${ }^{15-17}$ Just a few of them explore the experience of being informed about the DS diagnosis. ${ }^{18-19}$ Therefore, there is a need for more research with families of children with DS that can help knowing more about how the families are aware of the DS diagnosis. Hence, the purpose of this study is to analyze how Brazilian parents appraise their child's diagnosis of DS.

The guiding framework for this study is the Resiliency Model of Family Stress, Adjustment, and Adaptation, ${ }^{20}$ a model developed by a team of family researchers who sought to understand how families cope and adapt to critical events, such as a child being diagnosed with DS. Researchers and clinicians have widely used it to examine how families deal with crises and to explore how family factors contribute to family adaptation.

There are two phases in the Resiliency Model: the adjustment phase and the adaptation phase. The adjustment phase is focused on how families respond to critical events that do not present major challenges and only require minor changes in how the family functions. In contrast, the adaptation phase focuses on how families respond to situations that require larger and more systematic changes in family functioning. Given all the challenges associated with DS, the adaptation phase is most applicable to families of children with DS. In the adaptation phase, a family's ability to adapt is influenced by family factors such as family demands, family appraisal, family resources, and family problem-solving and coping. Successful adaptation occurs when the family reaches a balance between the needs of the affected family member (e.g., the child with DS), the needs of other family members, and the needs of the family as a whole. ${ }^{20}$ 
Family appraisal is a key component of the Resiliency Model. ${ }^{20}$ This component includes how the family interprets the critical event (e.g., being informed about their child's diagnosis of DS ) or their current situation (e.g., raising a child with DS), their ability to manage or control their situation, and expectations regarding how the event or situation may impact the family. ${ }^{20}$ The more positive the family appraises or views the critical event or their current situation, the more likely it is that the family will find ways to cope and adapt to their situation. ${ }^{20}$

How the family adapts during the child with DS's first years of life is a process that occurs within a cultural context and involves the interaction of different factors that help create opportunities or conditions that facilitate coping. One of these factors is the family's appraisal of the diagnosis and their family situation is one of these factors. Therefore, we ask: how does the family view the diagnosis of Down Syndrome and their appraisal of the diagnosis?

Many families are successful in their efforts to face the challenges arising from the diagnosis of DS. How families appraise their situation plays an important role in this process. Thus, this study is justified because it is likely to provide important information that professionals can use to provide care that is tailored to meet the specific needs of families dealing with a new and possibly unexpected diagnosis of DS.

\section{METHOD}

This is a qualitative, exploratory study, guided by the Resiliency Model of Family Stress, Adjustment, and Adaptation. ${ }^{20}$

Nineteen mothers and one father participated in the study. To be eligible for participation, parents needed to: (a) have a child with DS between the ages of one to three, (b) live with the child in Belo Horizonte, Brazil or cities nearby, and (c) agree to be interviewed. Several strategies were used to recruit parents for the study. Initially, professionals who worked in institutions and associations that provide care to children with DS and their families helped to recruit six parents who met the eligibility criteria. Later, a group of families who have children with DS was contacted; information about the study was shared with group members and the researcher contacted those who were interested in participating. Finally, study participants helped to recruit other parents for the study. The final number of participants was 19 mothers and one father.

The participants chose the time and location of the interviews. Locations included their homes, place of work, or the institution where the child with DS received care. Data collection occurred between February to June 2016. The interview guide for the semi-structured interview included questions grounded in the Resiliency Model that were focused on when they were informed of their child's diagnosis and the first years of the child's life. The researcher who interviewed the parent kept field notes in a diary.

Before beginning data collection, the researcher underwent training with the researcher's mentors concerning how to conduct interviews and keep field notes. Then, a pilot interview was conducted with a parent. Findings from this interview are not included in this paper. The transcript of the pilot interview was reviewed, and some adjustments were made to the interview guide.

Parents who expressed interest in participating and met the eligibility criteria were contacted by phone. After they agreed to participate, the interview was scheduled. Before the start of the interview, the researcher answered questions and addressed any concerns. Then, the parent was asked to sign the Free and Informed Consent Term (TCLE). Permission to record the interviews was also obtained. All the parents who were contacted agreed to participate, except for a mother who seemed very interested initially but rescheduled once and later did not return. During the interviews, in addition to the researcher and the participant mother or father, other family members, such as children and parents, were present during some data collection sessions, always with the participants' consent. 
Theoretical saturation was the criterion used to stop the data collection. An analysis after interviews with 19 participants suggested that theoretical saturation had been reached and no new themes were identified. ${ }^{21}$

All of the interviews were digitally recorded and transcribed verbatim by the researcher. On average, the interviews took approximately 75 minutes. The researchers checked the transcripts of the recording with the audio recorders. The interviews were analyzed using a directed approach to content analysis. ${ }^{22}$ The software MAXQDA ${ }^{\odot}$, version 12.2.0 was used to manage the date. The transcribed interviews were numbered according to the order of completion. The names of the parents and the child with DS were replaced by the initials $M$ (mother), $P$ (father), and $C$ (child). Therefore, the final identification consists of the initial letter corresponding to the participant and the number equivalent to the order of the interview (e. g. C1, M1, P1, C2).

The framework for the study (i.e., the Resiliency Model) guided the definition of the preliminary categories. A first set of categories and subcategories was constructed, which included the context of the stressor event and the main factors that influence the family adaptation process according to the model. After this definition, two of the researchers (authors of this study) explored three interviews and coded the data. The codes were revised, verifying the homogeneity of their themes and their heterogeneity when compared to one another. Two researchers coded the same interview individually. The agreement between the codifications was verified, obtaining a Kappa index of 0.78 (0.75-1.00= excellent). Then, one of the researchers conducted the encoding. ${ }^{23}$

After this process, the categories of analysis were constructed based on the adopted framework. The study complied with National Health Council Resolution 466/2012.

\section{RESULTS}

Twenty participants were interviewed, being 19 mothers and one father, ranging in age from 19 to 48 years-old. The majority were married (17), and the participants' education level varied from the $4^{\text {th }}$ grade of elementary school to finished high school, which was predominant. Only 12 participants worked at the time of data collection. Concerning the monthly family income, a variation of $<1000$ reais up to $>5001$ reais was found. Fifteen interviewees reported having at least one health plan for the child with DS.

The ages of the 20 children with DS ages ranged from one year and 21 days to two years and nine months old. Ten of the children were female and ten were male. According to the participants, the children with DS had one or more of the following co-occurring conditions: prematurity, vision disorders, cardiopathy (with and without the need for surgical correction), jaundice, respiratory problems, gastrointestinal disorders (Hirschsprung's disease, congenital esophageal stricture/tracheoesophageal fistula, reflux), with 15 of the children requiring hospital admission after birth.

In the data analysis process, four categories based on the Resiliency Model were assessed. In this paper, however, only the findings from the following two categories will be discussed: information about the diagnosis of Down Syndrome given to the family and the family's appraisal of Down Syndrome.

\section{INFORMATION ABOUT THE DIAGNOSIS OF DOWN SYNDROME GIVEN TO THE FAMILY}

This category addressed aspects of the information the family received about the diagnosis of DS in the antenatal period and after birth. In five families, the diagnosis of DS was suspected during the antenatal period. Three of these mothers (M3, M4, M8) chose to confirm the diagnosis of DS through amniocentesis or chorionic villus sampling because they felt anxious about the fact that their child might have DS. Also, they said that prenatal diagnosis meant an opportunity to better prepare the family in the face of the unknown and unexpected. 
So I did the amniocentesis because I wanted to have the diagnosis and I did not want to have that doubt in my head, to question this "does it have a syndrome?" And keep that story in mind until it is born. I preferred to solve it (M4).

Because I listen to people who know it at the time of delivery, you know, I think it's harder because it was much better for me before, because, as I told you, I could work out the idea in my head. Accepting, knowing, and searching (M3).

M12, although she was informed of the suspicion of DS in prenatal care, chose not to confirm the diagnosis until the child was born. This decision caused her anguish, but it also allowed her to hope that the DS would not be confirmed.

Oh, I had that expectation that it was not, to wait for it to be born, I stayed the whole time of the pregnancy with that anguish, you know? But I was hoping it was not. So, I did not want to do it because the karyotype is the diagnosis, got it? Until then, I had only the probability; I did not have the diagnosis (M12).

In the case of $\mathrm{P} 1$, there was a suspicion of the diagnosis, but this was later discarded, and the diagnosis was not confirmed until the postnatal period. The fifteen other mothers received information about the suspicion and confirmation of the diagnosis after their child's birth.

Concerning the health professionals who informed the families about the suspicion or confirmation of the diagnosis, in eighteen families, the physician was the professional responsible for this communication. The pediatrician, gynecologist, obstetrician, resident, and geneticist were mentioned. Only one mother reported she was informed by a psychologist, and another mother is a health professional who reached the diagnosis on her own.

Even though months had passed since the diagnosis of DS, the participants described in great detail how the health professionals provided them with information about the suspected or confirmed diagnosis of DS. It is verified in the participants' interviews that the professional's interaction and posture towards the family are directly related to how satisfied the family was with the information received. Thus, parental satisfaction with how they were informed of the diagnosis was directly related to the professional's attitude and whether he or she demonstrated the skills and characteristics necessary for care at that moment, such as information on the syndrome, support, care, patience, and attention.

Only five families expressed satisfaction with how they received information from health professionals, and about how the professional interacted with the family.

She knew how to speak the words, she knew how to answer the moment I asked her, the questions I asked her she knew how to answer me, right, she made it clear, you know, everything, I was worried about it. She was excellent (M20).

Thirteen families expressed dissatisfaction with the information received, having mentioned in their interviews: lack of enlightening information; coldness; lack of care; lack of support; lack of connection with the professional who reported; improper time and place; improper professional posture; negative information about DS; and indifference.

The worst things a mother can hear about a child she's been talking about. [...] she said that she was special, that she was going to have hypotonia, she would have difficulty to suckle, to nurse, to get the breast (M9).

And he comes [the pediatrician] with the clipboard and says to the other mothers: "Your son was born with about three kilos and yours with about three kilos, yours with some kilos. He came to me, at last, and said: 'Your daughter was born two kilos and sixty grams, and with Down syndrome' in front of all mothers (M14).

M11 stated that, even before learning about her daughter's diagnosis, she was approached by a doctor who asked her to give her students permission to teach about $D S$, referring to her daughter as an object of study and without considering the presence of family. 
The information obtained through the discourse of P1 and M12 did not allow us to conclude how satisfied they were with the information received.

When reporting their dissatisfaction with the way they received the information, the participants suggest that communication with the family should be better qualified. They want health professionals to seek out additional information on DS and families living with DS; show more care, patience, and sensitivity towards the family; talk more openly with families and provide clear information. They also want professionals to emphasize the positive aspects of the child when talking with the parents, considering that it is the birth of a new being in the family, a reason for celebration and exaltation.

Being more affectionate to speak, having more patience to explain a little, seeking more knowledge (M13).

And it is a birth, it is a celebration. [...] It cannot be seen as a sad thing, no matter how frightening it may be to us. [...] I think he [professional] has to talk about good things [...] I think the person must have a little more skill to come, to congratulate, 'Congratulations!' And say: 'Look, your son has Down syndrome', explaining what that is, [...] (M4).

\section{FAMILY'S APPRAISAL OF DOWN SYNDROME}

This category approached the families' appraisal of the suspicion or confirmation of the DS diagnosis, seeking to understand the families' feelings and experiences concerning the information received. This category also presents the family's assessment of the situation of having a child with DS. It goes beyond the moment of diagnosis information and involves family organization and functioning, along with its values, goals, and expectations, which represent the identity of its members.

\section{Family appraisal of suspected and/or confirmed Down Syndrome}

It is important to emphasize that the participants' (mother or father) discourse represented the family's appraisal or view of the situation, expressing their perceptions as well as the views of other family members.

Regardless of whether it occurred in the pre or post-natal period, the participants referred to the information of the suspected or confirmed diagnosis as a difficult moment filled with negative feelings and experiences, and words such as shock, scare, pain, sadness, mourning, crying, despair, impotence, and frustration.

So the diagnosis is scary, it is mourning that people experience (M4).

It opens a 'hole' and you fall inside. And no one can save you. Oh, my, I started crying, it was hopeless. It was really bad! It was the worst day of my life! (M6).

Today, after all, we can talk, but it is mourning that you have no concept (M14).

Six mothers reported about the need to reconstruct the idealized image they had of their offspring during pregnancy as from the moment they received information on the diagnosis of DS.

Six of the mothers (M3, M4, M11, M13, M15, and M18) had children with DS with co-occurring conditions that required surgical intervention or specialized health care. For these mothers, concern about the co-occurring condition (e.g., a cardiac condition or problem with feeding) often took priority over concern about the DS.

Then no one there sees the syndrome, sees the difficulty of feeding, right? For everyone, C11 does not eat through the mouth, it uses gastrostomy. For everyone, that is the concern. No one remembers that she has Down syndrome; no one cares about it (M11).

So, the problem for me was not Down syndrome. What left me without 'floor', without air, without anything, was the cardiopathy, because I did not know what I was dealing with. [...] If C15 were born with the syndrome, my goodness... He would be happy, jumping with joy. This cardiopathy knocked me off my feet (M15). 


\section{Family appraisal of their situation - having a child with Down Syndrome}

How parents viewed or appraised the fact that their child had DS seemed to change over time in many of the families. That is, over time, the way parents viewed having a child with DS became much more positive.

When starting at the moment the diagnosis is discovered, the adaptation process allows the families the most positive evaluation of the situation. There was a greater union among family members (M4, M7, M8, M14, M17, M20), more happiness and joy in the family system (M5, M7, M9, $\mathrm{M} 15, \mathrm{M} 18, \mathrm{M} 20)$ for the caregiver, and the understanding that there are other problems considered worse than DS (M7, M8, M13, M14, M18, M20).

He brought joy, more harmony to our home. That happened. We combine more, we are happier. He brought joy into the house (M15).

Regarding the expectations of the family concerning the child, it is common to express the desire for their children to be happy, independent, and successful in their development. In parallel, there is fear of the future, especially due to the possibility of prejudice and not living enough to take care of their children.

Let him be happy and independent. Because, first, l'm not going to stay here for the rest of my life, neither I nor P7, and happy because he has to do the thing he likes, he has to be his way (M7).

I am very afraid of what I am going to suffer, from the prejudice of the people, I am very afraid, to see her suffer (M3).

It is observed that eight mothers refer to current family life as normal and quiet, although there are challenges and difficulties related to the process of family adaptation. M1, for example, reports that currently, DS does not change any family plan. The children of other mothers, such as M11 and M13, have diagnoses of esophageal stricture/tracheoesophageal fistula and Hirschsprung's disease, respectively, and still require special care from their families. Those mothers appreciate the situation of their children considering the expectations within the difficulties and limitations that are more pronounced than in children with only the diagnosis of DS.

My life was normal, we went out, and we used to live with my family. After it, everything in my life changed, now there is something else. It was a normal life (M11).

Before, it was much quieter. Now it is not. Nowadays, I say that people's stress levels increase, because it is a lot of tension [...] for him to become a good child, we, at home, come back to life for him and forget about other things, other plans we had (M13).

\section{DISCUSSION}

The timing of information on the diagnosis of DS was predominantly in the postnatal period. Similarly, in studies conducted in the United States, ${ }^{9}$ Chile, ${ }^{10}$ Brazil ${ }^{11}$ and the Netherlands, ${ }^{24}$ in 84 to $97 \%$ of the cases, the communication of the diagnosis about DS also after birth.

The best time to get news of the diagnosis may be different for each family. Some families believe that getting the diagnosis before the child's birth allows them to prepare for the arrival of the child and be more accepting of the child's condition. On the other hand, other families may believe that getting a prenatal diagnosis can lead to anxiety, feelings of anguish, and anticipated distress. ${ }^{7}$

The perspective of these parents suggests that expectant parents are likely to view the chance to decide when they want to learn the diagnosis as very valuable. The opportunity to choose allows them to make a decision based on what they believe will work best for them and their family. Health care professionals have to clarify what prenatal tests can and cannot do. They also need to clarify any risks associated with the different types of prenatal testing. 
About the health professionals who informed the families about the suspected or confirmed diagnosis, physicians have been responsible for informing the family, especially pediatricians, neonatologists, obstetricians, and geneticists. The nurse was also identified as an informant. ${ }^{9-11}$

The communication of the diagnosis to the patient or his/her relatives, in the case of the child, is part of the doctor's duties, and it is established in his code of professional ethics. ${ }^{25}$ It is important to emphasize, however, that all health professionals have specificities in their work, which contribute to a more effective communication process with the patient. ${ }^{26}$

Thus, the importance of other health professionals to be present with the doctor at the time of diagnosis of DS should be considered though, serving as sources of support, especially for the family, and favoring the family's coping with the stressor event.

Some studies factors corroborate the findings presented here regarding dissatisfaction with how parents are informed of their child's diagnosis of DS. Factors that have been reported as sources of increased dissatisfaction include the professionals: emphasized more of the negative aspects of having a child with DS than the positive aspects, ${ }^{9}$ provided little or no information about DS, used insensitive-sensitive and cold language. ${ }^{7,9-10}$ Concerning the experience of families with information on the diagnosis of DS, negative feelings are also described in other studies. ${ }^{7}$

It is likely that for most families, the diagnosis of DS is unexpected, unwanted (at least initially) by parents, and interferes with the way people experience this moment. This may partially explain parental dissatisfaction with how they were informed of the diagnosis of DS. There is growing evidence, however, that some parents are highly satisfied with how they were informed of their child's diagnosis. ${ }^{4-5}$

Regarding the professionals' attitude, it is important to reflect on the focus of care and teaching in the undergraduate courses, and the values and ethical commitments teachers adopt in the teachinglearning process. In the context mentioned by $\mathrm{M} 11$, for example, the students who accompanied the doctor learned about the phenotypic and clinical characteristics present in the DS but forgot to include the family of the child in their care, without valuing interaction with the family and the family's care.

The educational process remains strongly guided by a disjointed technical approach of everyday practice and the context of its reality and, for this reason, establishing a connection between technical teachings and the perception of social issues remains a challenge in professional practice. Medical training lacks preparation for communication, especially of bad or unexpected news, and health professionals often find it difficult to deal with such moments in practice. ${ }^{7}$

There is a lack of accurate and up-to-date information for parents at the time of the diagnosis, which speaks about the family experience of living with an individual with Down syndrome because most of the existing guidelines for directing their diagnosis do not specifically address this issue. The professional action is aimed at informing parents about the aspects of the disease and the health conditions associated with DS. ${ }^{5}$

Although this study does not focus on the evaluation of professional practice, the parents' description of what made the information moment unsatisfactory offers concrete elements to infer that, for these families, the information was not communicated in the best way. The professionals involved in this context needs qualification to enable them to soften the repercussion of information on the family. The aspects the families highlighted should be observed, which allowed them to evaluate how the professionals informed them as satisfactory, considering: to receive information about the syndrome, support, care, patience, and attention.

It is important to emphasize that some of the recommendations the families are in line with the recommendations of other studies for health professionals who deal directly with information concerning the diagnosis of DS. 5,9

When analyzing how family viewed the experience of being informed of their child's diagnosis of DS, it became clear that, if the child with DS has a condition that requires surgical intervention 
or specialized care, the focus for the family may shift: the focus may be on the co-occurring condition rather than the DS. For some families, this may help in their overall adaptation because it gives them a chance to accept or get used to the fact that their child has DS.

Similar results were identified in a study conducted with parents of individuals with DS. It was common in the description of the participating mothers that the multiple health conditions of their child acted as the main stressor of the experience of being a mother of a child with DS. ${ }^{27}$

In this context, it is inferred that although information on the diagnosis of DS represents undesirable news and generates the family's negative appraisal when receiving it, some factors, such as information that health professionals do not clarify, the natural process of transforming the idealized child into the real child, and the association of other diagnoses besides DS, may contribute to accentuate the family's negative appraisal when faced with the stressor event.

Considering that the family's assessment of the diagnosis of DS interferes with its adaptation process, the more negative the assessment, the greater the chances of causing an imbalance and disorganization in the family system and, consequently, causing negative repercussions in the adaptation process.

Therefore, the more positive the family appraisal about the stressor event and the situation it causes, the easier the family will find ways to cope with it, develop problem-solving and coping, and adapt to the situation. ${ }^{20}$

It is important to help families develop a more positive appraisal of life with an individual with DS, by giving parents a balanced perspective, one that includes both positive aspects and the negative aspects of life with DS. One of the keys to helping parents adapt to the birth of a child with DS is identifying possible misconceptions parents may have about DS. Healthcare professionals also need to increase parental awareness of the advances that have been made in the care and treatment of individuals with DS. New parents need to know that individuals with DS are living longer and more fulfilling lives and that many are making important contributions to our society.

About the appraisal of the situation of having a child with DS, for the mothers and father of this study, the period of coexistence with the child from birth, the reorganization of the family system based on the demands DS poses, and learning to deal with the inherent challenges, along with the help of support networks, were important in modifying the family's initial assessment of the DS diagnosis, favoring their appraisal of the situation at the time of data collection.

In a study of mothers of disabled children, a more positive appreciation of the family is also possible, starting from the overcoming process, when compared to the moment the disability was diagnosis. ${ }^{28}$

The family's expectations regarding the child are also addressed in other studies of children with intellectual insufficiency, and they mainly involve motor development, schooling, and autonomy. ${ }^{1-2}$

Generally, any family expects their children to grow independently, to be happy, and to develop satisfactorily. The parents of children with DS present the same expectations, but are aware of their limitations, recognize the challenges and difficulties to be faced to reach such expectations, and demonstrate respect for the child's time. The uncertainty and fear for the future of the child with DS, and their care in the absence of the parents, also appears in other studies as a source of concern for families. ${ }^{7,27,29}$

The importance of further studies on the subject is emphasized, as they continue to explore DS and these families' adaptation process, especially in other age groups, aiming to understand the family system in other stages of the life of individuals with DS. One limitation of this study is the fact that the perception of the diagnosis of DS was only investigated and analyzed from the perspective of the children's mothers and fathers. Thus, studies are needed that permit apprehending the perspective of other relatives who live with the child with DS, thus allowing greater depth and understanding about these families' family system. 


\section{CONCLUSION}

The family's appraisal of the diagnosis of DS and the situation experienced is an important element in the family adaptation process and can contribute to good or bad adaptation.

Given the diagnosis information during pregnancy or at birth, parents refer to negative feelings and experiences, however, in general, they express a more positive appraisal about the situation of having a child with DS over time, which suggests that facing the adaptation process is important to modify the family's perception and can contribute to its outcome.

Understanding the diagnosis of DS from the perspective of the children's parents, that is, of those who experience the adaptation process, contributes to the identification of skills necessary for the health professionals who deal with the information context of the diagnosis of DS for family members, to favor their appraisal of the stressful event. Also, it allows health professionals involved in child care to identify the family's weaknesses and potentialities to act effectively, contributing to the successful adaptation of the family.

\section{REFERENCES}

1. Bergström S, Carr H, Petersson G, Stephansson O, Bonamy AK, Dahlström A, et al. Trends in congenital heart defects in infants with Down syndrome. Pediatrics [Internet]. 2016 [cited 2019 Mar 05];138(1):e20160123. Available from: https://doi.org/10.1542/peds.2016-0123.

2. Anderson BR, Blancha VL, Duchon JM, Chai PJ, Kalfa D, Bacha EA, et al. The effects of postoperative hematocrit on shunt occlusion for neonates undergoing single ventricle palliation. J Thorac Cardiovasc Surg [Internet]. 2017 [cited 2018 Nov 14];153(4):947-55. Available from: https://doi.org/10.1016/j.jtcvs.2016.09.085.

3. Kazemi M, Salehi M, Kheirollahi M. Down Syndrome: Current Status, Challenges and Future Perspectives. Int J Mol Cell Med [Internet]. 2016 [cited 2018 Nov 14];5(3):125-33. Available from: https://www.ncbi.nlm.nih.gov/pmc/articles/PMC5125364/

4. Choi EK, Yoo IY. Resilience in Families of Children with Down Syndrome in Korea. Int J Nurs Pract [Internet]. 2015 [cited 2018 Mai 06];21:532-41. Available from: https://doi.org/10.1111/ijn.12321.

5. Choi H, Van Riper M. Maternal Perceptions to Open-Ended Questions about Life with Down Syndrome in Korea. Qual Res J [Internet]. 2016 [cited 2018 Oct 15];21(2):288-98. Available from: https://nsuworks.nova.edu/tqr/vol21/iss2/7.

6. Oliveira LC, Eduardo IM, Prudente COM, Ribeiro MFM. Estresse em pais de crianças e adolescentes com síndrome de Down. Rev EVS [Internet]. 2018 [cited 2018 Oct 15];45(1):46-54. Available from: https://doi.org/10.18224/evs.v45i1.5786

7. Luisada V, Fiamenghi-Jr GA, Carvalho SG, Assis-Madeira EA, Blascovi-Assis SM. Experiências de médicos ao comunicarem o diagnóstico da deficiência de bebês aos pais. Ciênc Saúde [Internet]. 2015 [cited 2018 Aug 23];8(3):121-8. Available from: https://doi.org/10.15448/1983652X.2015.3.21769

8. Bolentini, M, Ferreira LL, Magalhães A. Síndrome de down x maternagem: Impacto do diagnóstico na relação mãe-bebê. Rev Fragm Cult [Internet]. 2018 [cited 2018 Aug 10];28:40-53. Available from: https://doi.org/10.18224/frag.v28i2.6142.

9. Skotko B. Mothers of children with Down Syndrome reflect on their postnatal support. Pediatrics [Internet]. 2005 [cited 2015 Aug 11];115(1):64-77. Available from: https://doi.org/10.1542/peds.20040928.

10. Paul María A, Cerda J, Correa C, Lizama M. ¿Cómo reciben los padres la noticia del diagnóstico de su hijo con síndrome de Down?. Rev Méd Chile [Internet]. 2013 [cited 2015 May 05];141(7):879-86. Available from: https://doi.org/10.4067/S0034-98872013000700007. 
11. Torres GL, Maia CE. Percepción de las madres acerca del contenido de la información del diagnóstico de Síndrome de Down. Rev Chil Pediatr [Internet]. 2009 [cited 2015 June 10];80(1):3947. Available from: https://doi.org/10.4067/S0370-41062009000100005

12. Reis LB, Paula KMPd. Coping materno da Síndrome de Down: identificando estressores e estratégias de enfrentamento. Estud Psicol [Internet]. 2018 [cited 2018 Dec 11];35(1):77-88. Available from: https://doi.org/10.1590/1982-02752018000100008

13. Rooke MI; Pereira-Silva NL. Indicativos de resiliência familiar em famílias de crianças com síndrome de Down. Estud Psicol [Internet]. 2016 [cited 2016 Dec 06];33(1):117-26. Available from: https://doi.org/10.1590/1982-027520160001000012

14. Rooke MI, Pereira-Silva NL, Crolman SR, Almeida BR. Funcionamento familiar e rede social de apoio: famílias com crianças com síndrome de down. Gerais, Rev Interinst Psicol [Internet]. 2019 [cited 2019 Apr 16];12(1):142-58. Available from: https://doi.org/10.36298/gerais2019120111.

15. Torquato JÁ, Lança AF, Pereira D, Carvalho FG, Silva RD. A aquisição da motricidade em crianças portadoras de Síndrome de Down que realizam fisioterapia ou praticam equoterapia. Fisioter Mov [Internet]. 2017 [cited 2018 Sept 20];26(3):515-25. Available from: https://doi.org/10.1590/ S0103-51502013000300005

16. Araujo, AGS; Scartezini, CM; Krebs, RJ. Análise da marcha em crianças portadoras de síndrome de down e crianças normais com idade de 2 a 5 anos. Fisioter Mov [Internet]. 2007 [cited 2018 Nov 03];20(3):79-85. Available from: https://periodicos.pucpr.br/index.php/fisio/article/view/18923/18297

17. Santos AM, Lobo VCT, Lourenço MGF. Perfil da função respiratória de crianças portadoras de Síndrome de Down na faixa etária de 5 a 12 anos. Fisioter Bras [Internet]. 2009 [cited 2018 Nov 03];10(3):153-8. Available from: https://doi.org/10.33233/fb.v10i3.1521

18. Hannum JSS, Miranda FJ, Salvador IF, Cruz AD. Impacto do diagnóstico nas famílias de pessoas com Síndrome de Down: revisão da literatura. Pensando Fam [Internet]. 2018 [cited 2019 Feb 15];22(2):121-36. Available from: http://pepsic.bvsalud.org/scielo.php?script=sci_ arttext\&pid=S1679-94X2018000200009\&lng=pt\&nrm=iso

19. Azócar E, Cerda J, Mella M. Experiencias en madres con hijos con síndrome de Down en torno a la recepción del diagnóstico. Rev Chil Salud Pública [Internet]. 2017 [cited em 2018 Oct 15];21(2):113-122. Available from: https://doi.org/10.5354/0719-5281.2017.48903

20. McCubbin MA, McCubbin HI. Families Coping with illness: the resiliency model of family stress, adjustment, and adaptation. In: Danielson C, Hamel-Bissell B, Winstead-Fry P. Families, health and illness: perspectives on coping and intervention. St. Louis, MO (US): Mosby; 1993. p.21-63.

21. Nelson J. Using conceptual depth criteria: addressing the challenge of reaching saturation in qualitative research. Qual Res J [Internet]. 2016 [cited 2018 Sept 20];17(5):554-70. Available from: https://doi.org/10.1177/1468794116679873.

22. Hsieh HF, Shannon SE. Three approaches to qualitative content analysis. Qual Health Res [Internet]. 2005 [cited 2015 Aug 05];15(9):1277-88. Available from: https://doi.org/10.1177/1049732305276687

23. Cicchetti DV. Guidelines, criteria, and rules of thumb for evaluating normed and standardized assessment instruments in psychology. Psychol Assess [Internet]. 1994 [cited 2018 June 10];6:284-90. Available from: https://doi.org/10.1037/1040-3590.6.4.284

24. Groot-Van der Mooren MD, Gemke RJBJ, Cornel MC, Weijerman ME. Neonatal diagnosis of Down syndrome in the Netherlands: suspicion and communication with parents. J Intellect Disabil [Internet]. 2014 [cited 2015 Nov 06];58(10):953-61. Available from: https://doi.org/10.1111/jir.12125

25. Conselho Federal de Medicina. Código de ética médica. Resolução CFM n 1.931 , de 17 de setembro de 2009. Available from: https://portal.cfm.org.br/images/stories/biblioteca/codigo\%20de $\% 20$ etica\%20medica.pdf 
26. Arrais RH, Jesuino SLCS. A vivência psicológica da comunicação sobre diagnóstico e tratamento por pacientes oncológicos: uma perspectiva da Psicologia Analítica. Rev SBPH [Internet]. 2015 [cited 2017 Feb 13];18(2):22-44. Available from: http://pepsic.bvsalud.org/scielo.php?script=sci_ arttext\&pid=S1516-08582015000200003\&lng=pt

27. Goff BSN, Monk JK, Malone J, Staats N, Tanner A, Springer NP. Comparing parents of children with Down syndrome at different life span stages. J Marriage Fam [Internet]. 2016 [cited 2018 Oct 04];78(4):1131-48. Available from: https://doi.org/10.1111/jomf.12312

28. Guerra C, Dias MD, Filha MOF, Andrade FB, Reichert APS, Araújo VS. Do sonho a realidade: vivência de mães de filhos com deficiência. Texto Contexto Enferm [Internet]. 2015 [cited 2019 Nov 28];24(2):459-66. Available from: https://doi.org/10.1590/0104-07072015000992014

29. Kortchmar E, Jesus MCP, Merighi MAB. Vivência da mulher com um filho com síndrome de down em idade escolar. Texto Contexto Enferm [Internet]. 2014 [cited 2019 Nov 28];23(1):13-20. Available from: https://doi.org/10.1590/S0104-07072014000100002 


\section{NOTES}

\section{ORIGIN OF THE ARTICLE}

Taken from the thesis - The perspective of primary caregivers on the diagnosis of Down Syndrome and the family's adaptation process in the first years of the child's life, presented to the Graduate Program at the Escola de Enfermagem, Universidade Federal de Minas Gerais, in 2017.

\section{CONTRIBUTION OF AUTHORITY}

Study design: Schettini DLC, Van Riper M, Duarte ED.

Data collection: Schettini DLC, Van Riper M, Duarte ED.

Data analysis and interpretation: Schettini DLC, Van Riper M, Duarte ED.

Discussion of the results: Schettini DLC, Van Riper M, Duarte ED.

Writing and/or critical review of the content: Schettini DLC, Van Riper M, Duarte ED.

Review and final approval of the final version: Schettini DLC, Van Riper M, Duarte ED.

\section{APPROVAL OF ETHICS COMMITTEE IN RESEARCH}

Approved in the Research Ethics Committee at the Universidade Federal de Minas Gerais, opinion 1425028 CAAE: 52605115.7.0000.5149.

\section{CONFLICT OF INTERESTS}

No conflicts of interest to declare.

\section{HISTORY}

Received: August 22, 2019.

Approved: January 28, 2020.

\section{CORRESPONDING AUTHOR}

Elysângela Dittz Duarte

elysangeladittz@gmail.com 